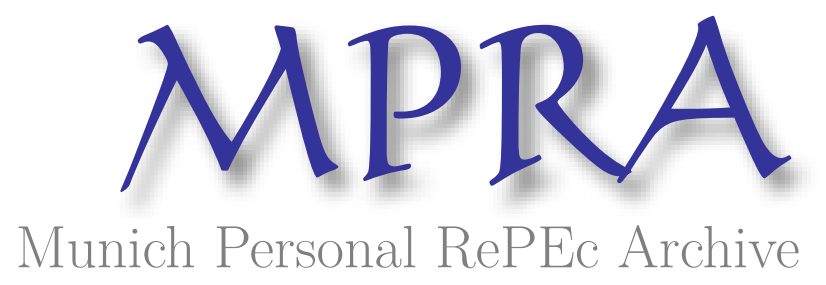

\title{
How Does Democratization Affect the Composition of Government Expenditure?
}

Kotera, Go and Okada, Keisuke

6 October 2015

Online at https://mpra.ub.uni-muenchen.de/67085/

MPRA Paper No. 67085, posted 06 Oct 2015 09:41 UTC 


\title{
How Does Democratization Affect the Composition of Government Expenditure?*
}

\author{
Go Kotera ${ }^{\dagger}$ \\ Ministry of Finance Japan
}

\author{
Keisuke Okada ${ }^{\ddagger}$ \\ Kansai University
}

October 2015

\begin{abstract}
This study examines the effects of democratization on the size and composition of government expenditure using the data of 125 countries between 1972 and 2010 at most. Specifically, we focus not only on the total expenditure but also on their composition and employ dichotomous indices of political regimes rather than score indices. Moreover, we construct instruments for democratization based on the democratization wave and conduct an instrumental variables estimation to address endogeneity problems. Our results show that while democratization does not have a significant impact on total expenditure, it increases expenditure on health and education and decreases expenditure on defense. Furthermore, considering the time-varying effect of democratization, defense expenditure starts decreasing immediately after a regime change and health expenditure increases in the medium and long run, while they do not significantly vary before a regime change. Thus, while focusing only on total expenditure does not uncover the effects of democratization, considering detailed categories of government expenditure enables us to understand how democratization changes governments' behaviors.
\end{abstract}

Keywords: Democratization; Government behavior; Government expenditure JEL Classification: H10; H50; P16

${ }^{*}$ The views expressed in this paper are those of the authors and do not necessarily reflect those of the Ministry of Finance Japan. Okada gratefully acknowledges financial support from the JSPS Grant-in-Aid for Young Scientists (B) (No. 26780163) and JSPS Grant-in-Aid for Scientific Research (B) (No. 15H03354).

${ }^{\dagger}$ Policy Research Institute, Ministry of Finance Japan, 3-1-1 Kasumigaseki, Chiyoda-ku, Tokyo 100-8940, Japan. Tel: + 8133581 4111, Fax: +81 35251 2113, E-mail: go.kotera@mof.go.jp

${ }^{\ddagger}$ Faculty of Economics, Kansai University, 3-3-35 Yamate-cho, Suita-shi, Osaka 564-8680, Japan. Tel: +81 66368 0623, Fax: +81 66339 7704, E-mail: k_okada@kansai-u.ac.jp 


\section{Introduction}

The "Third Wave of Democratization" (Huntington, 1991) has given birth to a number of newly democratic countries. In addition, recent years have witnessed various democratization movements around the world (e.g., the Arab spring in 2010 and pro-democracy protests in Hong Kong in 2014). Democratization or political regime change can largely affect subsequent public policies because it involves various institutional changes including the political process. In order to uncover the effect of democratization on public policies, this study empirically investigates changes in the size and composition of government expenditure before and after democratization, using a dataset of 125 countries from 1972 to 2010 at most.

While many previous studies examine the effect of political regimes on public policies, their results are not simply comparable because they cover different periods and countries and use different estimation methodologies. Moreover, some earlier works focus on specific expenditure or policy outcomes, or use the political regime index as one of the additional control variables. Our study differs from them in the following aspects. First, we employ the data on central government expenditure as a share of gross domestic product (GDP) and specifically consider total expenditure and six subcategories of expenditure, namely expenditure on health, education, social protection, defense, economic affairs, and general public services. Therefore, we examine the comprehensive and detailed effects of democratization on public policies. In addition, by focusing on expenditure rather than policy outcomes, we can capture the change in a government's behavior after excluding the effects of the efficiency of its regime and other political factors. ${ }^{1}$

Second, we use dichotomous indices of political regimes and estimate a difference-in-differences model, considering that democratized countries are the treated group and non-reforming countries are the control group. Most of the previous empirical studies in economics focusing on the effects of political regimes employ a score index of democracy such as the Freedom House measures and the Polity score. However, using a score index may not be suitable for investigating the effects of regime transition, because it cannot distinguish the effects of a regime change from those of the performance of each regime. Gradstein and Milanovic (2004, p. 516) point out that "quality of governance or political instability are conceptually different from democracy: they address political performance of a system, not its inherent (democratic or not) features." Furthermore, they give an example of countries that have the same polity scores but show differences in terms of political stability. $^{2}$ Therefore, we mainly analyze the effect of permanent democratization, which is defined as a transition to a democracy without reverse transitions in the sample period. ${ }^{3}$ This is because the consolidation of the institutions should be considered in order to investigate the effect of regime

\footnotetext{
${ }^{1}$ Nelson (2007) points out that democracy increases education and health spending but does not necessarily improve their outcomes, and that institutional reform in a democracy plays an important role in securing better results. Similarly, Acemoglu et al. (2015) show that democratization can be constrained by various factors such as the elite's investment in his/her political power, population heterogeneity, and power transfer to the middle class rather than to the poor. They find empirical evidence that democratization increases total tax revenues as a share of GDP but has a limited impact on decline in inequality.

${ }^{2}$ The definition and the classification of "political regime" have been controversial topics in political science. See, for example, Diamond (2002) and Svolik (2012, Chapter 2).

${ }^{3}$ In this paper, permanent democratization and successful democratization can be used interchangeably.
} 
transitions. In other words, we focus on the effects of the event of democratization given the good performance/consolidation of the associated institutions.

Third, we carefully address endogeneity problems. In reality, democratization is not a random event, and thus, it can be correlated with various economic conditions. Moreover, any dichotomous regime index can be subject to misclassification, and concerns about omitted variables are common to most empirical works. In addition, focusing only on permanent democratization can aggravate endogeneity concerns because a regime index includes information on the future state of institutions, as pointed out by Acemoglu et al. (2014). To deal with these problems, we employ an instrumental variables (IV) method. Inspired by Aidt and Jensen (2013) and Acemoglu et al. (2014), we use the number of democratizations in neighboring countries as an instrument for democratization.

Finally, we investigate the time-varying effects of democratization. Since political regime transitions have a large and broad impact on the whole society, democratization shows both lead and lag effects, which reflect individuals' expectations and the consolidation of institutions. Then, these timevariant effects can lead to a non-monotonic relationship between democratization and government expenditure. ${ }^{4}$ In addition, our estimation procedure can suffer from misspecification, as pointed by Laporte and Windmeijer (2005). Therefore, following Papaioannou and Siourounis (2008b), we divide the periods before and after the regime change into five subperiods (pre-transition, transition, short-run democratization, medium-run democratization, and long-run democratization) and examine the effects of democratization in each period. Considering flexible time-varying treatment effects also alleviates the causal problem between democratization and public expenditure.

Our main findings are as follows. Democratization does not have a significant impact on total expenditure. Considering each category of government expenditure, among redistributive policies, democratization significantly increases expenditure on health and education, whereas it does not affect expenditure on social protection. Instead, expenditure on defense significantly decreases after democratization. Furthermore, considering the timing of democratization, defense expenditure starts decreasing immediately after the regime change, and health expenditure increases in the medium and long run. Thus, we find that an increase in health expenditure due to democratization takes place relatively slowly. In addition, we show that the expenditure on general public services decreases in all subperiods.

There is a vast literature on the relationship between public expenditure and political regimes. Meltzer and Richard (1981), Boix (2003), and Acemoglu and Robinson (2005) suggest that democratization promotes left-wing policies through an extension of franchise to poor citizens. Meanwhile, Keefer (2007) points out that the majority of new democratic governments from 1975 to 2004 were right-wing rather than left-wing. His finding indicates that expenditure on left-wing policies such as health, education, and social protection may not increase after democratization, thus refuting the above theories. Nevertheless, most of the previous studies show that democracy tends to increase some social sector spending. Brown and Hunter (1999), Kaufman and Segura-Ubiergo (2001), and Avelino et al. (2005) use a dichotomous political regime index developed by Alvarez et al. (1996)

\footnotetext{
${ }^{4}$ Papaioannou and Siourounis (2008b) show the J-curve effect of democratization on economic growth; the economy expands in the pre-transition period, is stagnant in the transition period, and experiences higher growth in the posttransition period.
} 
and examine the effect of democracy on social spending in Latin American countries. All of them show a positive relationship between democracy and education spending, and Kaufman and SeguraUbiergo (2001) additionally find a positive effect on health spending and a negative effect on social security spending. Persson and Tabellini (2003) present an attempt to solve these questions, using a broader panel data set of 60 countries between 1960 and 1998. They find a positive relationship between welfare spending and democracy measured by the Gastil index and the Polity score. On the other hand, Mulligan et al. (2010) conduct a cross-country analysis and show that democracy does not increase, but decreases, social security expenditure if GDP per capita and population are controlled.

Expenditure on defense can be affected by several factors that are irrelevant to social sector spending, because military power is an important source of political power inside and outside the country. For example, particularly in a dictatorship, while military power gives authorities the ability to repress the masses and neighboring countries, excessive reliance on it empowers the military, which is a potential political rival of the authorities (Svolik, 2012). Political importance of military power is generally considered to be larger in a dictatorship than in a democracy, because a dictatorship does not have formal mechanisms of power transition, and violence is the ultimate measures to obtain power. ${ }^{5}$ Therefore, military spending tends to be higher in a dictatorship. Empirically, previous studies such as Dunne et al. (2008), Albalate et al. (2012), and Töngür et al. (2015) show a robust negative relationship between the Polity index and military expenditure.

Similar to our study, some earlier works focus on the composition of government expenditure. Easterly and Rebelo (1993) conduct a cross-country analysis and show that the political regime does not affect fiscal variables except for aid revenue. Habibi (1994) finds positive effects of political liberty, measured by Gastil's political rights index, on the budget shares of health and social security and a negative effect on that of defense. Moreover, Mulligan et al. (2004) show that higher levels of democracy decrease military spending but have an insignificant impact on nonmilitary government consumption, education spending, and social spending. Shelton's (2007) and Profeta et al.'s (2013) recent studies are closely related. Shelton (2007) comprehensively investigates the determinants of the size and composition of government expenditure, and employs the political rights index devised by Freedom House as one of the explanatory variables. Using a dataset covering about 100 countries from 1970 to 2000, he examines the interaction effects of democracy and income inequality and shows that when evaluated at the mean of the Gini coefficient, higher political rights increase total and social security spending and decrease expenditure on public order and safety. The major differences between Shelton's (2007) work and this study are as follows. First, we employ dichotomous indices of political regimes in order to reveal the effect of a regime change. Second, while Shelton (2007) estimates a random effects model to address the measurement error problem, our estimation model includes country and year fixed effects to alleviate the omitted variable problem. Using the Polity score and civil liberty index devised by Freedom House, Profeta et al. (2013) examine the effect of democracy on taxation and public expenditure in developing countries. They find that the

\footnotetext{
${ }^{5}$ This argument implicitly assumes that a democracy is sufficiently consolidated. According to Baliga et al. (2011), limited democracies, where restrictions on political leaders are not strong, are likely to be more involved in militarized disputes than in dictatorships.
} 
relationship between democracy and public spending, except defense expenditure, is insignificant, if fixed effects are included. In particular, our study differs from that of Profeta et al. (2013) in terms of the regime index and coverage of countries. Moreover, in contrast with these studies, we attempt to address the endogeneity of democratization.

Notably, the above empirical studies pay little attention to endogeneity problems. However, since democratization is an endogenous event, expectation of future fiscal policies, for example, can give rise to democratization in the current period, or some unobserved factors can affect both government expenditure and democratization. To the best of our knowledge, Aidt and Jensen (2013) and Acemoglu et al. (2014) are exceptional studies as they explicitly address the endogeneity of democratization. Aidt and Jensen (2013) study the rise in social spending in the 19th century and find a positive relationship between public spending per capita and franchise extension. Built on the theoretical studies by Boix (2003) and Acemoglu and Robinson (2005), they employ the weighted sum of the number of revolutionary events in neighboring countries as an instrument. Acemoglu et al. (2014) examine effects of political regime transitions on economic growth using a panel dataset of 175 countries from 1960 to 2010 and their original dichotomous regime index. Based on the idea of regional "waves" of democratization, which refers to the spread of democracy from one country to other countries in a region, their instrument for the political regime is defined as the average degree of democracy in other countries in the same region whose initial regimes are identical to that of a given country. ${ }^{6}$ Inspired by these studies, we construct an instrument for democratization by summating the number of neighboring democratized countries weighted by the geographical distance.

Furthermore, Papaioannou and Siourounis' (2008a, 2008b) studies are also closely related to this paper. Employing Papaioannou and Siourounis' (2008a) new dataset of permanent democratization for the period 1960-2005, Papaioannou and Siourounis (2008b) show a positive relationship between democratization and economic growth. We adopt their regime index and use a similar estimation methodology to investigate the effects of successful democratization on the composition of government expenditure. Although Papaioannou and Siourounis (2008b) do not apply IV techniques, they examine the time-varying effect of democratization in order to consider the causal problems. Following them, this study also conducts a similar analysis and additionally implements IV estimation.

This paper is organized as follows. In section 2, we explain our estimation methodology. Section 3 describes the data and explains the construction of the expenditure variables. Section 4 presents the results of the estimation and robustness checks, and discusses them. Section 5 concludes.

\section{Estimation methodology}

To examine the effects of democratization on the size and composition of government expenditure, we use the annual data of 125 countries over the period 1972-2010. We estimate an equation specified

\footnotetext{
${ }^{6}$ Empirical evidence for the democratic wave is provided by, for example, Persson and Tabellini (2009).
} 


$$
\text { Government expenditure }_{i t}=\alpha D_{i t}+\boldsymbol{\beta}^{\prime} \mathbf{X}_{i t}+\eta_{t}+u_{i}+\epsilon_{i t},
$$

where subscripts $i$ and $t$ represent a country and year, respectively. $\eta$ is a year-specific effect, $u$ is a country-specific effect, and $\epsilon$ is an error term. Government expenditure refers to total government expenditure and various categories of government expenditure as shares of GDP. These variables are in the natural logarithm. $D$ is democratization, which is a dichotomous variable, and more specifically, is defined as one in the subsequent years after a country is democratized and zero otherwise. It is noted that this variable is zero if a country has always had a democratic or autocratic regime. We explain the definitions and sources of government expenditure and democratization in more detail in the next section. $\mathbf{X}$ encompasses a constant, a dummy for the accrual basis of accounting, and other control variables, such as real GDP per capita, total population, fraction of population between the ages 0 to 14 as a share of the total population, fraction of population aged 65 and above as a share of the total population, trade openness defined as the sum of exports and imports divided by GDP, income inequality, and inflation. All these control variables, except for inflation and a dummy for the accounting system, are in the natural logarithm. GDP per capita represents the level of economic development in a country. As the literature on Wagner's law (e.g., Easterly and Rebelo, 1993) shows, economic development influences the size and composition of government expenditure. The effects of a larger population on public expenditure are ambiguous, because more heterogeneous preferences require various public services, and non-rivalness of public goods decreases per capita cost of public goods provision (Alesina and Wacziarg, 1998). Moreover, larger population shares of young and elderly people can increase health, education, and social protection expenditure. Trade openness can be positively related with the size of the government, as pointed out by Rodrik (1998). In the robustness checks, we also control for income inequality and inflation, because previous studies find that these variables are associated with the size of the government. Meltzer and Richard (1981) show that higher income inequality causes more redistribution. Brender and Drazen (2013) control for inflation to examine the effect of an election on the composition of government spending since Brender and Drazen (2008) find that inflation affects leadership changes in developed countries. Finally, the data of government expenditure are measured by cash and accrual bases of accounting, as explained in detail in the next section. Therefore, following Seiferling (2013), to control for differences in accounting systems, we include a dummy for the accrual basis of accounting, which is equal to one if the data of the accrual basis accounting are used and zero otherwise.

We conduct the fixed effects estimation, which enables us to control for country-fixed effects such ethnolinguistic, geographical, and cultural factors. For example, ethnic diversity and climate conditions, which are almost time-invariant in the sample period, can affect the size and composition of government expenditure. Shelton (2007), who examines the determinants of the composition of government expenditure, intends to consider measurement errors of government expenditure and then uses the random effects estimation. Because the random effects estimation does not control for country-specific effects, he adds various time-invariant explanatory variables such as electoral systems and ethnic fractionalization. On the other hand, we consider that addressing country- 
specific effects is more important in a country-level panel data analysis, and thus, we employ a fixed effects estimation.

Our estimation model is a difference-in-differences model like the one used by Papaioannou and Siourounis (2008b). The treated group is democratization countries and the control group is non-reforming countries, which include countries that have always been democratic and those that have always been autocratic. The difference-in-differences model of democratization has several concerns; in particular, the democratization variable should be strictly exogenous for the estimator to be unbiased. If democratization is likely to occur when the size and composition of government expenditure show some trends, the coefficient of the democratization variable reflects those trends and can be biased upwards or downwards. Therefore, we conduct an IV estimation to tackle endogeneity problems. In addition, we also examine time-varying effects of democratization on the government budget to deal with the concerns pointed out by Laporte and Windmeijer (2005). Finally, to address the downward bias of the difference-in-differences estimators, we employ adjusted standard errors allowing for country-level heteroskedasticity and autocorrelation, following Bertrand et al. (2004).

\section{Data}

The data used in this study are drawn from various databases and several previous papers. Depending upon the availability of datasets, we collected the annual data of 125 countries over the period 1972-2010. The countries in our sample are listed in Table A1 of the Appendix.

The data of government expenditure are obtained from the Historical Government Finance Statistics (GFS) CD-ROM provided by the International Monetary Fund (IMF, 2005) and the Government Finance Statistics CD-ROM (IMF, 2013). The Historical GFS is constructed according to the Government Finance Statistics Manual (GFSM) 1986 and provides the data from 1972 to 1989. On the other hand, the GFS is based on GFSM 2001 and covers the data from 1990 onwards. Because GFSM 1986 and GFSM 2001 have different methodologies, these two databases are not easily merged together. ${ }^{7}$ Therefore, we follow Acosta-Ormaechea and Morozumi (2013) to merge these two databases in order to obtain a longer panel dataset of government expenditure.

We face four main concerns while merging the two databases. First, the classifications of the Historical GFS and GFS are different; more specifically, the former has 14 categories, and the latter, 10. Wickens (2002) explains how one may reclassify GFSM 1986 classification categories as GFSM 2001 categories. Following Wickens (2002), we convert the data of the Historical GFS to the classification categories in GFSM 2001. Then, we can use ten functional categories in GFSM 2001: (1) general public services, (2) defense, (3) public order and safety, (4) economic affairs, (5) environmental protection, (6) housing and community amenities, (7) health, (8) recreation, culture, and religion, (9) education, and (10) social protection. Among them, we focus on total expenditure and the following six subcategories, which are likely to be related to democratization: expenditure on health, education, social protection, defense, economic affairs, and general public services. Second,

\footnotetext{
${ }^{7}$ Wickens (2002) describes the differences between these two databases in more detail.
} 
GFSM 1986 and GFSM 2001 have different accounting bases. The former reports a cash basis, whereas the latter mainly reports an accrual basis. Regarding this concern, Seiferling (2013, p. 9) states, "Although there does not exist a technically sophisticated method for converting cash data to accrual (or vice versa), for practical purposes, it is acceptable to merge these data for most series and include a dummy variable in parametric analysis to control for any systematic differences that may exist." Following his argument, we include a dummy for the accrual basis of accounting. In addition, for countries that report both accounting bases within a given year in the GFS, we use the data based on the accrual basis. Third, while the Historical GFS provides the data of consolidated central governments only, the GFS additionally provides the data of the consolidated general governments. To ensure consistency in this study, we use the data of the consolidated central governments for both databases. ${ }^{8}$ Finally, although the GFS includes the data as a share of GDP, the Historical GFS does not. Therefore, GDP data before 1989 are obtained from the World Economic Outlook Databases constructed by the IMF (1999).

The data of democratization are obtained from Papaioannou and Siourounis (2008a), Cheibub et al. (2010), and Acemoglu et al. (2014). Papaioannou and Siourounis (2008a) and Acemoglu et al. (2014) focus on the democratization of 174 countries over the period 1960-2005 and 183 countries over the period 1960-2010, respectively. While Acemoglu et al. (2014) construct the data referring to Papaioannou and Siourounis (2008a), these two data are notably different, one of the major differences being that Papaioannou and Siourounis (2008a) focus on the permanent changes to a democratic regime, whereas Acemoglu et al. (2014) examine all transitions to democracy and reversals. Since we account for the consolidation of democracy, as described above, we mainly use the democratization data constructed by Papaioannou and Siourounis (2008a) as they are. Furthermore, they classify democratization into "full," "partial," and "borderline" democratization, using the Polity and Freedom House indicators. They define full democratization, partial democratization, and borderline democratization as democratization where democratic institutions have been fully consolidated, substantial democratic progress has occurred, and democratic progress has taken place but the protection of civil liberties is still very poor, respectively. In addition, they consider reversals from democracy to autocracy. Examining 174 countries, they identify 39 full, 24 partial, 6 borderline democratizations, and 3 reversals. Among 122 countries in our sample when we use Papaioannou and Siourounis' (2008a) data, there are 34 full, 17 partial, 6 borderline democratizations, and 2 reversals. Unless otherwise noted, we regard democratization as full democratization. The data constructed by Cheibub et al. (2010) and Acemoglu et al. (2014) and the detailed classification of democratization by Papaioannou and Siourounis (2008a) are employed in the robustness checks. We list countries and their democratization years in Table A1 of the Appendix.

The data of other control variables such as GDP per capita, total population, fraction of population between ages 0 to 14 as a share of the total population, fraction of population aged 65 and above as a share of the total population, trade openness, and inflation are obtained from the World Development Indicators provided by the World Bank (2014). Finally, income inequality,

\footnotetext{
${ }^{8}$ We do not consider the difference of fiscal decentralization across countries, because the data on local governments are limited, and the sample size becomes too small.
} 
which is the Gini coefficient of household income, is taken from Solt's (2009) study. ${ }^{9}$ Table A2 of the Appendix summarizes data definitions and sources, and Table A3 of the Appendix shows the descriptive statistics.

\section{Empirical results}

\subsection{Basic results}

Table 1 presents our basic estimation results, in which we regard democratization as full democratization, as defined by Papaioannou and Siourounis (2008a). We use the data of 122 countries over the period 1972-2005. In column (1), the coefficient of democratization on total government expenditure as a share of GDP is not significant. Next, we examine whether the government conducts specific redistributive policies after democratization. In columns (2)-(4), we consider the health, education, and social protection expenditure divided by GDP. Among them, only health expenditure significantly increases after democratization, in line with the predictions of the models à la Meltzer and Richard (1981). Column (5) indicates that democratization decreases military spending, which is similar to the previous studies. ${ }^{10}$ A good example of this result is the case of Chile between 1973 and 1989, which was ruled by the military junta headed by Augusto Pinochet. In this period, the maximum value of military expenditure was $4.15 \%$ in 1974 . Military expenditure decreased after democratization in 1990 and reached 0.96\% in 2008. The Republic of Korea (South Korea) also fits this scenario. After World War II, Park Chung Hee and Chun Doo Hwan governed South Korea via military dictatorship. While military expenditure was $5.94 \%$ in 1981 , it decreased after democratization and fell to $2.22 \%$ in 2002. Columns (6) and (7) show that democratization negatively impacts expenditure on economic affairs and general public services, but these effects are not significant.

[Table 1 here]

In Table 2, we control for inequality and inflation. Despite controlling for these variables, we obtain the same results as in Table 1, that is, democratization significantly increases health expenditure and decreases defense expenditure. ${ }^{11}$

[Table 2 here]

\footnotetext{
${ }^{9}$ We employ the Standardized World Income Inequality Database (Version 4.0) developed by Solt (2009).

${ }^{10}$ The expenditure on defense can be affected by wars. We also control for a dummy variable for war, which equals one if there are at least 1000 battle-related deaths and zero otherwise. This variable is constructed using the UCDP/PRIO Armed Conflict Dataset v.4-2014a, 1946-2013, which is provided by Gleditsch et al. (2002) and Themnér and Wallensteen (2014). The results remain unchanged even if we include this dummy variable.

${ }^{11}$ We conduct the same regression analyses, using government expenditure as a share of total government expenditure instead of as a share of GDP. As explained in section 3, we merge the data measured by the cash and accrual bases of accounting. If we use government expenditure as a share of total government expenditure, the differences between the accounting bases seem to be less of a problem. In this analysis, as in Table 1, democratization significantly increases health expenditure and decreases defense expenditure. In addition, educational expenditure significantly increases after democratization.
} 


\subsection{Alternative democratization indices}

In this section, we use two different indices of democratization in order to confirm the robustness of the results. We construct the data pertaining to successful democratization based on Acemoglu et al. (2014) in the following manner. We define an index of successful democratization as one that meets the following conditions: (1) the country's democratization is the most recent in the sample period and, (2) its final democratic regime had persisted at least for five years until the end of the sample period. Cheibub et al. (2010) provide the minimalist dichotomous measure of democracy and dictatorship covering 199 countries from 1946 to 2008. ${ }^{12}$ Applying the same two conditions, we also create an index of successful democratization based on the dataset constructed by Cheibub et al. (2010).

First, Table 3 provides the estimation results when we employ successful democratization based on the data of Acemoglu et al. (2014). The dataset includes 125 countries between 1972 and 2010 . As in Tables 1 and 2, democratization has a significantly positive impact on health expenditure and a significantly negative effect on defense expenditure. In addition, in column (6), democratization significantly decreases expenditure on economic affairs.

[Table 3 here]

Second, Table 4 shows the estimation results when we use successful democratization based on the data by Cheibub et al. (2010). We use the data of 124 countries over the period 1972-2008. Then, only health expenditure significantly increases after democratization, as seen in column (3). The measure of political regime by Cheibub et al. (2010) is based on a minimalist approach, and the number of democratized countries is fewer than that of two other measures. For example, Estonia and Ukraine have always been democratic since independence, while Papaioannou and Siourounis (2008a) and Acemoglu et al. (2014) consider that these countries democratized in 1992 and 1994, respectively. These differences seem to cause somewhat different estimation results compared with the cases of two other democratization indices.

[Table 4 here]

\subsection{Instrumental variables estimation}

In this section, we conduct a panel IV estimation to address endogeneity problems. Motivated by Aidt and Jensen (2013) and Acemoglu et al. (2014), we construct the instruments for democrati-

\footnotetext{
${ }^{12}$ Similar to Alvarez et al. (1996), Cheibub et al. (2010) simply define a democracy if a country satisfies the following two conditions: (1) both the chief executive office and the legislative body must be filled by elections, and (2) contestation occurs when there exists an opposition that has some chance of winning office as a consequence of elections.
} 
zation as follows. ${ }^{13}$

$$
Z_{i t}=\left\{\begin{array}{cl}
\sum_{j \neq i} \frac{1}{N_{t}-1}\left(1-\frac{\delta^{i j}}{\delta}\right) D_{j t} & \text { if } S_{i t}=0 \\
0 & \text { if } S_{i t}=1
\end{array}\right.
$$

where $\delta^{i j}$ is the time-invariant great-circle distance between the capitals of countries $i$ and $j, \delta$ is half the length of the equator, and $N_{t}$ is the number of countries in the world. $S_{i t}$ is zero if a country is autocratic and one if it is democratic. $D_{j t}$ is a democratization variable as in Eq. (1) and its construction is based on 39 full democratization episodes as in Papaioannou and Siourounis' (2008a) study. When constructing the instrument, we use 174 countries, all of which are included in the dataset provided by Papaioannou and Siourounis (2008a). The data pertaining to distance are drawn from Mayer and Zignago's (2011) study.

Our identification strategy is that democratization is affected by (exogenous) democratization in other countries. Since democratization occurs only in dictatorial countries, the instrument takes zero when a country is a democratic, and the instrument is affected by democratization in other countries all over the world. In the third wave of democratization (Huntington, 1991), many countries in Latin America were democratized in the 1980s, and many countries in Eastern Europe and Africa were democratized in the 1990s after the collapse of the Soviet Union. In addition, democratization in other countries is unlikely to influence government behavior directly. Therefore, our constructed IV for democratization are valid in that the instruments are highly correlated with democratization in a given country and do not directly influence the dependent variable. Because the democratization wave seems to affect political regimes after a certain period of time, we use the first, second, and third lags of $Z$ as the instruments for democratization.

Table 5 shows the panel IV estimation results. We first confirm the validity of the instruments from the statistical viewpoint. In all columns, the $F$-values for the tests of the excluded instruments in the first-stage regressions exceed 10, satisfying the "rule of thumb" proposed by Staiger and Stock (1997). Moreover, the Hansen tests of overidentifying restrictions do not reject the orthogonality conditions at the conventional significance level in all columns.

[Table 5 here]

The results in Table 5 are similar to those in Tables 1 and 2; democratization significantly increases health expenditure and decreases defense expenditure. A notable difference is that democratization also has a significant positive impact on educational expenditure, as seen in column $(3)$.

\subsection{Time-varying effects}

The effects of democratization on the composition of government expenditure may not be monotonic. For example, dictatorships facing the threat of democratization may increase armaments to suppress

\footnotetext{
${ }^{13}$ Acemoglu et al. (2014) consider that the democratization wave occurs in the same region. On the other hand, we think that democratization in a country is affected by democratization in other countries in the world, and the extent of this effect is inversely proportional to the distances between the countries. Persson and Tabellini (2009) and Aidt and Jensen (2013) also adopt this type of weight as influences from foreign countries.
} 
their citizens, while military expenditure decreases after democratization. Furthermore, Laporte and Windmeijer (2005) point out that fixed effects estimators with binary indicator variables can suffer from misspecification when treatment effects are not constant over time. To address this concern, they propose that we should use flexible time-varying treatment effects. Therefore, we follow Papaioannou and Siourounis (2008b) and examine the timing of the effect of democratization. Specifically, we estimate the following equation.

$$
\begin{aligned}
\text { Government expenditure }_{i t} & =\alpha_{1} D_{i t}^{1}+\alpha_{2} D_{i t}^{2}+\alpha_{3} D_{i t}^{3}+\alpha_{4} D_{i t}^{4}+\alpha_{5} D_{i t}^{5} \\
& +\boldsymbol{\beta}^{\prime} \mathbf{X}_{i t}+\eta_{t}+u_{i}+\epsilon_{i t} .
\end{aligned}
$$

Consider that a country is democratized when $t=T$. $D^{1}$ is defined as one if $t=T-5, T-4, T-3$; $D^{2}$ is defined as one if $t=T-2, T-1, T ; D^{3}$ is defined as one if $t=T+1, T+2, T+3 ; D^{4}$ is defined as one if $t=T+4, T+5, T+6$; and $D^{5}$ is defined as one if $t \geq T+7$. All these dummy variables are equal to zero in the years that are not specified.

Table 6 shows the estimation results. As shown below in detail, we do not find a non-monotonic relationship between democratization and expenditure. In column (1), democratization does not have a significant impact on total government expenditure in all periods around the transition. In column (2), the expenditure on health increases in the medium and long run, and its impact is larger in the long run. In columns (3) and (4), the expenditure on education and social protection do not change for any timing of democratization. In column (5), the expenditure on defense decreases immediately after democratization, and its impacts are larger in the medium and long run. Democratization does not have a significant impact on the expenditure on economic affairs, as seen in column (6). In column (7), the expenditure on general public services decreases through all periods. This result differs from those in Tables 1 and 2, and classifying the timings of democratization can capture the different effects on the expenditure on general public services.

[Table 6 here]

\subsection{Different types of transitions}

In this section, we examine the different effects depending on the types of democratization. We employ Papaioannou and Siourounis' (2008a) four classifications of political regime transitions, namely full, partial, and borderline democratizations, and reversals, and we simultaneously include these dummy variables in the regression equation. This analysis not only serves as a robustness check for the results obtained so far but also investigates how incomplete democratization and reverse transition change governments' behaviors. ${ }^{14}$

In all columns, the coefficients and significances of full democratization are almost the same as in Tables 1 and 2. In contrast, partial democratization has a positive effect only on the expenditure

\footnotetext{
${ }^{14}$ Since the end of the Cold War, most of the countries practicing dictatorship have nominally adopted democratic political institutions (Diamond, 2002) and thus, have become partially democratized. All the countries classified as partially democratized by Papaioannou and Siourounis (2008a) were democratized in the 1990s, except for Serbia and Montenegro and Turkey.
} 
on general public services (see column (8)). These results suggest that the effect of partial democratization on government expenditure is quite different from that of full democratization. Borderline democratization has a negative impact on expenditure on health, education, and general public services (see columns (2), (3), and (7), respectively), whereas it has a positive impact on expenditure on social protection, as seen in column (4). Moreover, the reverse transition from a democracy to a dictatorship increases total expenditure (see column (1)) and expenditure on social protection (see column (4)). If the reverse transition gives rise to effects opposite to those of democratization, the sign of coefficient of the reversals dummy should be opposite to that of (full) democratization. Thus, our results seem to be inconsistent. Because our sample includes only two countries that have undergone reversal, Gambia and Zimbabwe, it is difficult to judge whether the results reflect the political events in these two countries over a period or if they are generalized (i.e., apply to all reversals). ${ }^{15}$ The same caveat also applies to the results for borderline democratization because only six countries are classified as such in our sample.

[Table 7 here]

\subsection{Discussion}

In this section, we summarize the results obtained so far and discuss them. Our estimation results show that democratization has no significant impact on total government expenditure as a share of GDP. On the other hand, considering specific categories of government expenditure, we find that the expenditure on health and education significantly increases after democratization. These results concerning redistributive policies are largely consistent with the consequences of the democratization models based on Meltzer and Richard (1981), whereas the effect on social protection expenditure is insignificant. Moreover, our results show a decrease in the expenditure on defense. A decline in military spending after democratization is consistent with the previous empirical studies that use score regime indices (Dunne et al., 2008; Albalate et al., 2012; Töngür et al., 2015).

When considering the time-varying effects of democratization, both changes in expenditure on health and defense are observed only after regime transition. In particular, the increase in health expenditure becomes gradually larger in the medium and long run. This suggests that dictatorships may not significantly change their policies regarding health and military spending even if they expect democratization, and that redistributive policies are implemented as democracy is consolidated. Furthermore, we also find that democratization significantly decreases the expenditure on general public services before and after regime transition. The interpretation of this result is somewhat difficult, but this may reflect the chaos in general governmental functions in the midst of a regime transition, given that the expenditure on general public services includes expenses for financial and fiscal affairs and diplomacy. ${ }^{16}$

\footnotetext{
${ }^{15}$ An increase in total expenditure in countries classified under the category "reversals" may especially reflect the events in Zimbabwe. Zimbabwe witnessed a reversal in 1987. Its total government expenditure as a share of GDP was $29.70 \%$ in 1986 and increased to $40.34 \%$ in 1996.

${ }^{16}$ As a further check, we estimate Eq. (3) after replacing dummy $D^{5}$ with two new dummies, $D^{6}$ and $D^{7}$, which are respectively defined as one if $t=T+7, T+8, T+9$ and if $t \geq T+10$. Then, the coefficient of $D^{7}$ is insignificant, while $D^{2}, D^{3}, D^{4}$, and $D^{6}$ have significant negative impacts. This result suggests that the effect of democratization
} 
Furthermore, focusing on various types of democratization, partial democratization affects the government expenditure differently from full (permanent) democratization. Specifically, partial democratization increases the expenditure on general public services only. This finding suggests that partially democratized countries, most of which are former socialist and African countries democratized in the 1990s, may hardly change their policies even after democratization. ${ }^{17}$

Overall, focusing only on total expenditure does not allow us to uncover the change in governments' behaviors after democratization. However, considering detailed categories of government expenditure enables us to understand how democratization affects governments' behaviors. That is, while democratization increases some social sector spending, it simultaneously decreases the expenditure on defense. As a result, the size of government expenditure does not seem to be influenced by democratization.

\section{Concluding remarks}

More countries have become democratic in recent times. Thus, it has become more important to investigate how political regime changes influence subsequent public policies. Using the data of 125 countries between 1972 and 2010 at most, this study examines how democratization affects the size and composition of government expenditure. To reveal the detailed changes pertaining to democratization in governments' behaviors, we focus on six subcategories of expenditure, namely health, education, social protection, defense, economic affairs, and general public services, and total expenditure. In addition, we construct the IV for democratization based on historical events of the democratization wave to deal with the endogeneity of democratization. Our results show that while democratization does not have a significant impact on total expenditure, it has significant impacts on certain subcategories of expenditure. Among redistributive policies, democratization significantly increases expenditure on health and education, although it does not affect expenditure on social protection. Instead, expenditure on defense significantly decreases after democratization. Furthermore, considering the timing of democratization, defense expenditure starts decreasing immediately after a regime change and health expenditure increases in the medium and long run, while these types of expenditure do not significantly change before a regime change. We also show that the expenditure on general public services decreases in all subperiods.

This study uses dichotomous measures and focuses on successful democratization. While our approach can capture the effect of a regime change given the quality of institutions, the scope of a political regime and its transition is not broad. Although we investigate the effects of various types of democratization in section 4.5, the analyses on incomplete democratization and reverse transition may not be sufficient because countries that are not fully democratized and non-democracies can take various forms. In particular, since the collapse of the Soviet Union, many dictatorial countries are likely to mimic democracies, and this tendency is fostered by increasing international intervention in

on the expenditure on general public services is transitory rather than permanent. This may also explain why the negative effect on the expenditure on general public services is insignificant in the other analyses.

${ }^{17}$ This result is similar to the effect of democratization on economic growth. Papaioannou and Siourounis (2008b) show that partial democratization does not have a significant positive effect on growth. 
non-democracies (Diamond, 2002). In order to examine the recent global wave of democratization, we should obtain a more rich understanding of regime types and transition mechanisms. These are important and interesting topics for future research, both in the empirical and theoretical sense.

\section{Appendix}

See Tables A1-A3.

[Table A1 here]

[Table A2 here]

[Table A3 here]

\section{References}

[1] Acemoglu, D., Naidu, S., Restrepo, P., Robinson, J. A., 2014. Democracy does cause growth. NBER Working Paper, No. 20004.

[2] Acemoglu, D., Naidu, S., Restrepo, P., Robinson, J. A., 2015. Democracy, redistribution, and inequality. In: Atkinson, A. B., Bourguignon, F. (Eds.), Handbook of Income Distribution, Volume 2, Elsevier, Amsterdam, pp. 1885-1966.

[3] Acemoglu, D., Robinson, J. A., 2005. Economic Origins of Dictatorship and Democracy. Cambridge University Press, Cambridge.

[4] Acosta-Ormaechea, S., Morozumi, A., 2013. Can a government enhance long-run growth by changing the composition of public expenditure? IMF Working Paper, WP/13/162.

[5] Aidt, T. S., Jensen, P. S., 2013. Democratization and the size of government: evidence from the long 19th century. Public Choice 157 (3-4), 511-542.

[6] Albalate, D., Bel, G., Elias, F., 2012. Institutional determinants of military spending. Journal of Comparative Economics 40 (2), 279-290.

[7] Alesina, A., Wacziarg, R., 1998. Openness, country size and government. Journal of Public Economics 69 (3), 305-321.

[8] Alvarez, M., Cheibub, J. A., Limongi, F., Przeworski, A., 1996. Classifying political regimes. Studies in Comparative International Development 31 (2), 3-36.

[9] Avelino, G., Brown, D. S., Hunter, W., 2005. The effects of capital mobility, trade openness, and democracy on social spending in Latin America, 1980-1999. American Journal of Political Science 49 (3), 625-641. 
[10] Baliga, S., Lucca, D. O., Sjöström, T., 2011. Domestic political survival and international conflict: is democracy good for peace? Review of Economic Studies 78 (2), 458-486.

[11] Bertrand, M., Duflo, E., Mullainathan, S., 2004. How much should we trust differences-indifferences estimates? Quarterly Journal of Economics 119 (1), 249-275.

[12] Boix, C., 2003. Democracy and Redistribution. Cambridge University Press, Cambridge.

[13] Brender, A., Drazen, A., 2008. How do budget deficits and economic growth affect reelection prospects? Evidence from a large panel of countries. American Economic Review 98 (5), 22032220 .

[14] Brender, A., Drazen, A., 2013. Elections, leaders, and the composition of government spending. Journal of Public Economics 97, 18-31.

[15] Brown, D. S., Hunter, W., 1999. Democracy and social spending in Latin America, 1980-92. American Political Science Review 93 (4), 779-790.

[16] Cheibub, J. A., Gandhi, J., Vreeland, J. R., 2010. Democracy and dictatorship revisited. Public Choice 143 (1-2), 67-101.

[17] Diamond, L., 2002. Thinking about hybrid regimes. Journal of Democracy 13 (2), 21-35.

[18] Dunne, J. P., Perlo-Freeman, S., Smith, R. P., 2008. The demand for military expenditure in developing countries: hostility versus capability. Defense and Peace Economics 19 (4), 293-302.

[19] Easterly, W., Rebelo, S., 1993. Fiscal policy and economic growth: an empirical investigation. Journal of Monetary Economics 32 (3), 417-458.

[20] Gleditsch, N. P., Wallensteen P., Eriksson, M., Sollenberg, M., Strand, H., 2002. Armed conflict 1946-2001: a new dataset. Journal of Peace Research 39 (5), 615-637.

[21] Gradstein, M., Milanovic, B., 2004. Does libertè = egalité? A survey of the empirical links between democracy and inequality with some evidence on the transition economies. Journal of Economic Surveys 18 (4), 515-537.

[22] Habibi, N., 1994. Budgetary policy and political liberty: a cross-sectional analysis. World Development 22 (4), 579-586.

[23] Huntington, S. P., 1991. The Third Wave: Democratization in the Late Twentieth Century. University of Oklahoma Press, Norman.

[24] International Monetary Fund, 1999. World Economic Outlook Database September 1999. International Monetary Fund, Washington, D.C.

[25] International Monetary Fund, 2005. Historical Government Finance Statistics. International Monetary Fund, Washington, D.C. 
[26] International Monetary Fund, 2013. Government Finance Statistics. International Monetary Fund, Washington, D.C.

[27] Kaufman, R. R., Segura-Ubiergo, A., 2001. Globalization, domestic politics, and social spending in Latin America: a time-series cross-section analysis, 1973-97. World Politics 53 (4), 553-587.

[28] Keefer, P., 2007. The poor performance of poor democracies. In: Boix, C., Stokes, S. C. (Eds.) The Oxford Handbook of Comparative Politics. Oxford University Press, New York, pp. 886909.

[29] Laporte, A., Windmeijer, F., 2005. Estimation of panel data models with binary indicators when treatment effects are not constant over time. Economics Letters 88 (3), 389-396.

[30] Mayer, T., Zignago, S., 2011. Notes on CEPII's distances measures: the GeoDist database. CEPII Working Paper, No. 2011-25.

[31] Meltzer, A. H., Richard, S. F., 1981. A rational theory of the size of government. Journal of Political Economy 89 (5), 914-927.

[32] Mulligan, C. B., Gil, R., Sala-i-Martin, X., 2004. Do democracies have different public policies than nondemocracies? Journal of Economic Perspectives 18 (1), 51-74.

[33] Mulligan, C. B., Gil, R., Sala-i-Martin, X. X., 2010. Social security and democracy. The B.E. Journal of Economic Analysis \& Policy 10 (1), Article 18.

[34] Nelson, J. M., 2007. Elections, democracy, and social services. Studies in Comparative International Development 41 (4), 79-97.

[35] Papaioannou, E., Siourounis, G., 2008a. Economic and social factors driving the third wave of democratization. Journal of Comparative Economics 36 (3), 365-387.

[36] Papaioannou, E., Siourounis, G., 2008b. Democratisation and growth. Economic Journal 118 (532), 1520-1551.

[37] Persson, T., Tabellini, G., 2003. The Economic Effects of Constitutions. MIT Press, Cambridge.

[38] Persson, T., Tabellini, G., 2009. Democratic capital: the nexus of political and economic change. American Economic Journal: Macroeconomics 1 (2), 88-126.

[39] Profeta, P., Puglisi, R., Scabrosetti, S., 2013. Does democracy affect taxation and government spending? Evidence from developing countries. Journal of Comparative Economics 41 (3), 684-718.

[40] Rodrik, D., 1998. Why do more open economies have bigger governments? Journal of Political Economy 106 (5), 997-1032.

[41] Seiferling, M., 2013. Recent improvements to the Government Finance Statistics Yearbook Database in response to analytical needs. IMF Working Paper, WP/13/15. 
[42] Shelton, C. A., 2007. The size and composition of government expenditure. Journal of Public Economics 91 (11-12), 2230-2260.

[43] Solt, F., 2009. Standardizing the world income inequality database. Social Science Quarterly $90(2), 231-242$.

[44] Staiger, D., Stock, J. H., 1997. Instrumental variables regression with weak instruments. Econometrica $65(3), 557-586$.

[45] Svolik, M. W., 2012. The Politics of Authoritarian Rule. Cambridge University Press, Cambridge.

[46] Themnér, L., Wallensteen, P., 2014. Armed conflicts, 1946-2013. Journal of Peace Research 51 (4), 541-554.

[47] Töngür, Ü., Hsu, S., Elveren, A. Y., 2015. Military expenditures and political regimes: evidence from global data, 1963-2000. Economic Modelling 44, 68-79.

[48] Wickens, T. M., 2002. Government Finance Statistics Manual 2001 Companion Material: Classification of GFSM 1986 Data to the GFSM 2001 Framework. International Monetary Fund, Washington, D.C.

[49] World Bank, 2014. World Development Indicators. World Bank, Washington, D.C. 
Table 1: Basic results

\begin{tabular}{|c|c|c|c|c|c|c|c|}
\hline & $\begin{array}{l}(1) \\
\text { Total }\end{array}$ & $\begin{array}{l}(2) \\
\text { Health }\end{array}$ & $\begin{array}{l}\text { (3) } \\
\text { Education }\end{array}$ & $\begin{array}{l}(4) \\
\text { Social } \\
\text { protection }\end{array}$ & $\begin{array}{l}(5) \\
\text { Defense }\end{array}$ & $\begin{array}{l}(6) \\
\text { Economic } \\
\text { affairs }\end{array}$ & $\begin{array}{l}(7) \\
\text { General } \\
\text { public } \\
\text { services }\end{array}$ \\
\hline Democratization & $\begin{array}{l}-0.029 \\
(0.050)\end{array}$ & $\begin{array}{l}0.388^{* * *} \\
(0.138)\end{array}$ & $\begin{array}{l}0.182 \\
(0.136)\end{array}$ & $\begin{array}{l}-0.044 \\
(0.081)\end{array}$ & $\begin{array}{l}-0.256^{* * *} \\
(0.071)\end{array}$ & $\begin{array}{l}-0.075 \\
(0.108)\end{array}$ & $\begin{array}{l}-0.199 \\
(0.143)\end{array}$ \\
\hline GDP per capita & $\begin{array}{l}-0.044 \\
(0.072)\end{array}$ & $\begin{array}{l}-0.175 \\
(0.210)\end{array}$ & $\begin{array}{l}0.076 \\
(0.138)\end{array}$ & $\begin{array}{l}-0.030 \\
(0.163)\end{array}$ & $\begin{array}{l}-0.150 \\
(0.154)\end{array}$ & $\begin{array}{l}0.375^{* *} \\
(0.148)\end{array}$ & $\begin{array}{l}-0.327 \\
(0.204)\end{array}$ \\
\hline Population & $\begin{array}{l}-0.306^{* *} \\
(0.138)\end{array}$ & $\begin{array}{l}0.584 \\
(0.484)\end{array}$ & $\begin{array}{l}-0.170 \\
(0.319)\end{array}$ & $\begin{array}{l}-0.194 \\
(0.295)\end{array}$ & $\begin{array}{l}-0.378 \\
(0.323)\end{array}$ & $\begin{array}{c}-0.593^{*} \\
(0.338)\end{array}$ & $\begin{array}{l}-0.630 \\
(0.416)\end{array}$ \\
\hline Fraction 14- & $\begin{array}{l}0.258 \\
(0.202)\end{array}$ & $\begin{array}{l}-0.911 \\
(0.689)\end{array}$ & $\begin{array}{l}0.706 \\
(0.588)\end{array}$ & $\begin{array}{l}-0.152 \\
(0.434)\end{array}$ & $\begin{array}{l}-0.120 \\
(0.351)\end{array}$ & $\begin{array}{l}0.911^{* *} \\
(0.385)\end{array}$ & $\begin{array}{l}-0.445 \\
(0.540)\end{array}$ \\
\hline Fraction $65+$ & $\begin{array}{l}0.196 \\
(0.164)\end{array}$ & $\begin{array}{c}-0.605^{*} \\
(0.359)\end{array}$ & $\begin{array}{l}0.028 \\
(0.228)\end{array}$ & $\begin{array}{l}0.749^{*} \\
(0.410)\end{array}$ & $\begin{array}{l}0.342 \\
(0.359)\end{array}$ & $\begin{array}{l}1.069^{* * *} \\
(0.370)\end{array}$ & $\begin{array}{l}-0.376 \\
(0.447)\end{array}$ \\
\hline Trade openness & $\begin{array}{l}0.119^{*} \\
(0.064)\end{array}$ & $\begin{array}{l}0.094 \\
(0.112)\end{array}$ & $\begin{array}{c}-0.134^{*} \\
(0.079)\end{array}$ & $\begin{array}{l}-0.086 \\
(0.114)\end{array}$ & $\begin{array}{l}0.074 \\
(0.140)\end{array}$ & $\begin{array}{l}0.241^{*} \\
(0.132)\end{array}$ & $\begin{array}{l}0.432^{* * *} \\
(0.124)\end{array}$ \\
\hline Countries & 122 & 110 & 110 & 109 & 107 & 109 & 110 \\
\hline Observations & 2355 & 1890 & 1900 & 1824 & 1778 & 1834 & 1871 \\
\hline
\end{tabular}

Notes: All variables except democratization are in the natural logarithm. All estimations include a constant term, year dummies, and a dummy for the accrual basis of accounting, although we do not report the results here. ***, **, and $*$ indicate the $1 \%, 5 \%$, and 10\% significance levels, respectively. The numbers in parentheses are robust standard errors clustered at the country level. 
Table 2: Extended results

\begin{tabular}{|c|c|c|c|c|c|c|c|}
\hline & $\begin{array}{l}(1) \\
\text { Total }\end{array}$ & $\begin{array}{l}(2) \\
\text { Health }\end{array}$ & $\begin{array}{l}(3) \\
\text { Education }\end{array}$ & $\begin{array}{l}(4) \\
\text { Social } \\
\text { protection }\end{array}$ & $\begin{array}{l}(5) \\
\text { Defense }\end{array}$ & $\begin{array}{l}(6) \\
\text { Economic } \\
\text { affairs }\end{array}$ & $\begin{array}{l}(7) \\
\text { General } \\
\text { public } \\
\text { services }\end{array}$ \\
\hline Democratization & $\begin{array}{l}-0.021 \\
(0.047)\end{array}$ & $\begin{array}{l}0.381^{* * *} \\
(0.133)\end{array}$ & $\begin{array}{l}0.255 \\
(0.155)\end{array}$ & $\begin{array}{l}-0.003 \\
(0.100)\end{array}$ & $\begin{array}{l}-0.285^{* * *} \\
(0.083)\end{array}$ & $\begin{array}{l}0.017 \\
(0.126)\end{array}$ & $\begin{array}{l}-0.135 \\
(0.143)\end{array}$ \\
\hline GDP per capita & $\begin{array}{c}-0.123^{*} \\
(0.072)\end{array}$ & $\begin{array}{l}-0.218 \\
(0.244)\end{array}$ & $\begin{array}{l}0.016 \\
(0.187)\end{array}$ & $\begin{array}{l}-0.186 \\
(0.174)\end{array}$ & $\begin{array}{l}-0.173 \\
(0.158)\end{array}$ & $\begin{array}{l}0.581^{* * *} \\
(0.186)\end{array}$ & $\begin{array}{c}-0.414^{*} \\
(0.216)\end{array}$ \\
\hline Population & $\begin{array}{c}-0.294^{*} \\
(0.160)\end{array}$ & $\begin{array}{l}0.833^{*} \\
(0.466)\end{array}$ & $\begin{array}{l}-0.183 \\
(0.389)\end{array}$ & $\begin{array}{l}0.021 \\
(0.305)\end{array}$ & $\begin{array}{l}-0.510 \\
(0.323)\end{array}$ & $\begin{array}{l}-0.459 \\
(0.353)\end{array}$ & $\begin{array}{l}-1.211^{* * *} \\
(0.376)\end{array}$ \\
\hline Fraction 14- & $\begin{array}{l}0.091 \\
(0.200)\end{array}$ & $\begin{array}{l}-0.983 \\
(0.660)\end{array}$ & $\begin{array}{l}0.711 \\
(0.728)\end{array}$ & $\begin{array}{l}-0.162 \\
(0.472)\end{array}$ & $\begin{array}{l}0.042 \\
(0.433)\end{array}$ & $\begin{array}{l}0.783^{*} \\
(0.442)\end{array}$ & $\begin{array}{l}0.025 \\
(0.647)\end{array}$ \\
\hline Fraction $65+$ & $\begin{array}{l}0.371^{* *} \\
(0.164)\end{array}$ & $\begin{array}{l}-0.514 \\
(0.470)\end{array}$ & $\begin{array}{l}0.237 \\
(0.244)\end{array}$ & $\begin{array}{l}1.016^{* *} \\
(0.414)\end{array}$ & $\begin{array}{l}0.822^{* *} \\
(0.390)\end{array}$ & $\begin{array}{l}0.873^{* *} \\
(0.384)\end{array}$ & $\begin{array}{l}0.331 \\
(0.572)\end{array}$ \\
\hline Trade openness & $\begin{array}{l}0.062 \\
(0.053)\end{array}$ & $\begin{array}{l}0.058 \\
(0.123)\end{array}$ & $\begin{array}{l}-0.179^{* *} \\
(0.084)\end{array}$ & $\begin{array}{l}-0.042 \\
(0.101)\end{array}$ & $\begin{array}{l}0.008 \\
(0.112)\end{array}$ & $\begin{array}{l}0.093 \\
(0.115)\end{array}$ & $\begin{array}{l}0.411^{* * *} \\
(0.125)\end{array}$ \\
\hline Inequality & $\begin{array}{l}-0.010 \\
(0.109)\end{array}$ & $\begin{array}{l}0.773^{* *} \\
(0.344)\end{array}$ & $\begin{array}{l}0.297 \\
(0.236)\end{array}$ & $\begin{array}{l}-0.113 \\
(0.237)\end{array}$ & $\begin{array}{l}-0.230 \\
(0.166)\end{array}$ & $\begin{array}{l}-0.280 \\
(0.248)\end{array}$ & $\begin{array}{l}-0.165 \\
(0.254)\end{array}$ \\
\hline Inflation & $\begin{array}{l}-0.000 \\
(0.000)\end{array}$ & $\begin{array}{l}-0.000 \\
(0.000)\end{array}$ & $\begin{array}{l}0.000 \\
(0.000)\end{array}$ & $\begin{array}{l}-0.000 \\
(0.000)\end{array}$ & $\begin{array}{l}0.000 \\
(0.000)\end{array}$ & $\begin{array}{l}-0.000 \\
(0.000)\end{array}$ & $\begin{array}{l}-0.000 \\
(0.000)\end{array}$ \\
\hline Countries & 104 & 91 & 91 & 89 & 89 & 91 & 91 \\
\hline Observations & 1798 & 1450 & 1455 & 1400 & 1394 & 1407 & 1444 \\
\hline
\end{tabular}

Notes: All variables except democratization and inflation are in the natural logarithm. All estimations include a constant term, year dummies, and a dummy for the accrual basis of accounting, although we do not report the results here. $* * *, * *$, and $*$ indicate the $1 \%, 5 \%$, and $10 \%$ significance levels, respectively. The numbers in parentheses are robust standard errors clustered at the country level. 
Table 3: Frist alterative democratization index

\begin{tabular}{llllllll}
\hline & $(1)$ & $(2)$ & $(3)$ & $(4)$ & $(5)$ & $(6)$ & $(7)$ \\
& Total & Health & Education & $\begin{array}{l}\text { Social } \\
\text { protection }\end{array}$ & Defense & $\begin{array}{l}\text { Economic } \\
\text { affairs }\end{array}$ & $\begin{array}{l}\text { General } \\
\text { public } \\
\text { services }\end{array}$ \\
\hline Democratization & -0.000 & $0.302^{* *}$ & 0.120 & -0.008 & $-0.212^{* * *}$ & $-0.229^{* *}$ & -0.026 \\
& $(0.050)$ & $(0.148)$ & $(0.134)$ & $(0.093)$ & $(0.063)$ & $(0.114)$ & $(0.159)$ \\
GDP per capita & -0.025 & 0.057 & 0.245 & -0.023 & -0.099 & $0.417^{* * *}$ & $-0.329^{*}$ \\
Population & $(0.063)$ & $(0.231)$ & $(0.153)$ & $(0.149)$ & $(0.142)$ & $(0.148)$ & $(0.192)$ \\
Fraction 14- & -0.133 & 0.485 & -0.034 & 0.188 & -0.300 & -0.441 & -0.622 \\
Fraction 65+ & $(0.131)$ & $(0.468)$ & $(0.332)$ & $(0.318)$ & $(0.298)$ & $(0.311)$ & $(0.380)$ \\
Trade openness & 0.080 & -0.895 & 0.480 & -0.266 & -0.253 & 0.479 & -0.345 \\
& $(0.198)$ & $(0.591)$ & $(0.651)$ & $(0.411)$ & $(0.348)$ & $(0.377)$ & $(0.508)$ \\
Countries & 0.076 & $-0.574^{*}$ & -0.053 & $0.916^{* *}$ & 0.125 & $0.707^{* *}$ & -0.316 \\
Observations & $(0.147)$ & $(0.345)$ & $(0.253)$ & $(0.383)$ & $(0.334)$ & $(0.323)$ & $(0.411)$ \\
\hline
\end{tabular}

Notes: All variables except democratization are in the natural logarithm. All estimations include a constant term, year dummies, and a dummy for the accrual basis of accounting, although we do not report the results here. ***, **, and $*$ indicate the $1 \%, 5 \%$, and $10 \%$ significance levels, respectively. The numbers in parentheses are robust standard errors clustered at the country level. 
Table 4: Second alterative democratization index

\begin{tabular}{llllllll}
\hline & $(1)$ & $(2)$ & $(3)$ & $(4)$ & $(5)$ & $(6)$ & $(7)$ \\
& Total & Health & Education & $\begin{array}{l}\text { Social } \\
\text { protection }\end{array}$ & Defense & $\begin{array}{l}\text { Economic } \\
\text { affairs }\end{array}$ & $\begin{array}{l}\text { General } \\
\text { public } \\
\text { services }\end{array}$ \\
\hline Democratization & 0.029 & $0.283^{*}$ & 0.132 & 0.007 & -0.057 & -0.147 & -0.036 \\
& $(0.052)$ & $(0.147)$ & $(0.131)$ & $(0.092)$ & $(0.111)$ & $(0.115)$ & $(0.159)$ \\
GDP per capita & -0.037 & -0.024 & 0.177 & -0.041 & -0.112 & $0.381^{* * *}$ & $-0.330^{*}$ \\
Population & $(0.063)$ & $(0.226)$ & $(0.144)$ & $(0.155)$ & $(0.148)$ & $(0.144)$ & $(0.199)$ \\
Fraction 14- & -0.191 & 0.502 & -0.126 & 0.012 & -0.327 & -0.475 & -0.606 \\
Fraction 65+ & $(0.130)$ & $(0.479)$ & $(0.327)$ & $(0.293)$ & $(0.304)$ & $(0.333)$ & $(0.389)$ \\
Trade openness & 0.140 & -0.943 & 0.633 & -0.227 & -0.205 & 0.607 & -0.316 \\
& $(0.200)$ & $(0.611)$ & $(0.633)$ & $(0.421)$ & $(0.343)$ & $(0.382)$ & $(0.523)$ \\
Countries & 0.101 & -0.472 & 0.048 & $0.825^{* *}$ & 0.054 & $0.834^{* *}$ & -0.345 \\
Observations & $(0.149)$ & $(0.358)$ & $(0.230)$ & $(0.397)$ & $(0.360)$ & $(0.352)$ & $(0.425)$ \\
\hline
\end{tabular}

Notes: All variables except democratization are in the natural logarithm. All estimations include a constant term, year dummies, and a dummy for the accrual basis of accounting, although we do not report the results here. ***, **, and $*$ indicate the $1 \%, 5 \%$, and $10 \%$ significance levels, respectively. The numbers in parentheses are robust standard errors clustered at the country level. 
Table 5: IV estimation

\begin{tabular}{|c|c|c|c|c|c|c|c|}
\hline & $\begin{array}{l}(1) \\
\text { Total }\end{array}$ & $\begin{array}{l}(2) \\
\text { Health }\end{array}$ & $\begin{array}{l}(3) \\
\text { Education }\end{array}$ & $\begin{array}{l}(4) \\
\text { Social } \\
\text { protection }\end{array}$ & $\begin{array}{l}(5) \\
\text { Defense }\end{array}$ & $\begin{array}{l}(6) \\
\text { Economic } \\
\text { affairs }\end{array}$ & $\begin{array}{l}(7) \\
\text { General } \\
\text { public } \\
\text { services }\end{array}$ \\
\hline Democratization & $\begin{array}{l}0.043 \\
(0.082)\end{array}$ & $\begin{array}{l}0.354^{*} \\
(0.193)\end{array}$ & $\begin{array}{l}0.298^{*} \\
(0.174)\end{array}$ & $\begin{array}{l}-0.115 \\
(0.247)\end{array}$ & $\begin{array}{l}-0.500^{* *} \\
(0.195)\end{array}$ & $\begin{array}{l}0.056 \\
(0.190)\end{array}$ & $\begin{array}{l}-0.148 \\
(0.210)\end{array}$ \\
\hline GDP per capita & $\begin{array}{l}-0.053 \\
(0.060)\end{array}$ & $\begin{array}{l}-0.141 \\
(0.218)\end{array}$ & $\begin{array}{l}0.066 \\
(0.142)\end{array}$ & $\begin{array}{l}-0.100 \\
(0.153)\end{array}$ & $\begin{array}{l}-0.062 \\
(0.149)\end{array}$ & $\begin{array}{l}0.472^{* * *} \\
(0.149)\end{array}$ & $\begin{array}{l}-0.347 \\
(0.213)\end{array}$ \\
\hline Population & $\begin{array}{l}-0.313^{* *} \\
(0.143)\end{array}$ & $\begin{array}{l}0.384 \\
(0.451)\end{array}$ & $\begin{array}{l}-0.353 \\
(0.343)\end{array}$ & $\begin{array}{l}-0.208 \\
(0.379)\end{array}$ & $\begin{array}{l}-0.451 \\
(0.325)\end{array}$ & $\begin{array}{l}-0.756^{* *} \\
(0.382)\end{array}$ & $\begin{array}{l}-0.571 \\
(0.402)\end{array}$ \\
\hline Fraction 14- & $\begin{array}{l}0.286 \\
(0.191)\end{array}$ & $\begin{array}{l}-0.782 \\
(0.684)\end{array}$ & $\begin{array}{l}0.869 \\
(0.589)\end{array}$ & $\begin{array}{l}-0.313 \\
(0.447)\end{array}$ & $\begin{array}{l}-0.045 \\
(0.382)\end{array}$ & $\begin{array}{l}1.025^{* *} \\
(0.398)\end{array}$ & $\begin{array}{l}-0.367 \\
(0.580)\end{array}$ \\
\hline Fraction $65+$ & $\begin{array}{l}0.194 \\
(0.163)\end{array}$ & $\begin{array}{l}-0.559 \\
(0.376)\end{array}$ & $\begin{array}{l}0.034 \\
(0.241)\end{array}$ & $\begin{array}{l}0.673^{*} \\
(0.408)\end{array}$ & $\begin{array}{l}0.498 \\
(0.368)\end{array}$ & $\begin{array}{l}1.121^{* * *} \\
(0.395)\end{array}$ & $\begin{array}{l}-0.359 \\
(0.502)\end{array}$ \\
\hline Trade openness & $\begin{array}{l}0.088 \\
(0.055)\end{array}$ & $\begin{array}{l}0.082 \\
(0.106)\end{array}$ & $\begin{array}{l}-0.200^{* * *} \\
(0.068)\end{array}$ & $\begin{array}{l}-0.079 \\
(0.117)\end{array}$ & $\begin{array}{l}0.054 \\
(0.124)\end{array}$ & $\begin{array}{l}0.191 \\
(0.121)\end{array}$ & $\begin{array}{l}0.390^{* * *} \\
(0.120)\end{array}$ \\
\hline F-value in the first stage & 23.49 & 19.38 & 20.23 & 21.52 & 15.77 & 21.47 & 20.54 \\
\hline Hansen test (p-value) & 0.12 & 0.12 & 0.76 & 0.32 & 0.64 & 0.19 & 0.17 \\
\hline Countries & 113 & 103 & 104 & 102 & 100 & 103 & 103 \\
\hline Observations & 2163 & 1741 & 1750 & 1676 & 1638 & 1690 & 1721 \\
\hline
\end{tabular}

Notes: All variables except democratization are in the natural logarithm. All estimations include a constant term, year dummies, and a dummy for the accrual basis of accounting, although we do not report the results here. The instruments for democratization are the first, second, and third lags of the constructed instruments, $Z$. ***, **, and * indicate the $1 \%, 5 \%$, and $10 \%$ significance levels, respectively. The numbers in parentheses are robust standard errors clustered at the country level. 
Table 6: Time-varying effects

\begin{tabular}{|c|c|c|c|c|c|c|c|}
\hline & $\begin{array}{l}(1) \\
\text { Total }\end{array}$ & $\begin{array}{l}(2) \\
\text { Health }\end{array}$ & $\begin{array}{l}(3) \\
\text { Education }\end{array}$ & $\begin{array}{l}(4) \\
\text { Social } \\
\text { protection }\end{array}$ & $\begin{array}{l}(5) \\
\text { Defense }\end{array}$ & $\begin{array}{l}(6) \\
\text { Economic } \\
\text { affairs }\end{array}$ & $\begin{array}{l}(7) \\
\text { General } \\
\text { public } \\
\text { services }\end{array}$ \\
\hline Pre democratization & $\begin{array}{l}-0.039 \\
(0.065)\end{array}$ & $\begin{array}{l}-0.075 \\
(0.114)\end{array}$ & $\begin{array}{l}0.057 \\
(0.096)\end{array}$ & $\begin{array}{l}0.007 \\
(0.064)\end{array}$ & $\begin{array}{l}0.089 \\
(0.104)\end{array}$ & $\begin{array}{l}-0.053 \\
(0.081)\end{array}$ & $\begin{array}{l}-0.311^{*} \\
(0.183)\end{array}$ \\
\hline Transition & $\begin{array}{l}-0.099 \\
(0.070)\end{array}$ & $\begin{array}{l}-0.105 \\
(0.116)\end{array}$ & $\begin{array}{l}-0.023 \\
(0.154)\end{array}$ & $\begin{array}{l}-0.025 \\
(0.090)\end{array}$ & $\begin{array}{l}-0.052 \\
(0.115)\end{array}$ & $\begin{array}{l}-0.087 \\
(0.086)\end{array}$ & $\begin{array}{l}-0.456^{* * *} \\
(0.144)\end{array}$ \\
\hline Short-run democratization & $\begin{array}{l}-0.094 \\
(0.070)\end{array}$ & $\begin{array}{l}0.172 \\
(0.139)\end{array}$ & $\begin{array}{l}0.233 \\
(0.190)\end{array}$ & $\begin{array}{l}-0.025 \\
(0.112)\end{array}$ & $\begin{array}{c}-0.205^{*} \\
(0.115)\end{array}$ & $\begin{array}{l}-0.156 \\
(0.112)\end{array}$ & $\begin{array}{l}-0.447^{* * *} \\
(0.161)\end{array}$ \\
\hline Medium-run democratization & $\begin{array}{l}-0.101 \\
(0.079)\end{array}$ & $\begin{array}{l}0.296^{*} \\
(0.156)\end{array}$ & $\begin{array}{l}0.193 \\
(0.194)\end{array}$ & $\begin{array}{l}-0.040 \\
(0.121)\end{array}$ & $\begin{array}{l}-0.273^{* * *} \\
(0.100)\end{array}$ & $\begin{array}{l}-0.131 \\
(0.119)\end{array}$ & $\begin{array}{l}-0.491^{* *} \\
(0.200)\end{array}$ \\
\hline Long-run democratization & $\begin{array}{l}-0.018 \\
(0.077)\end{array}$ & $\begin{array}{l}0.542^{* * *} \\
(0.193)\end{array}$ & $\begin{array}{l}0.199 \\
(0.202)\end{array}$ & $\begin{array}{l}-0.097 \\
(0.131)\end{array}$ & $\begin{array}{l}-0.270^{* *} \\
(0.115)\end{array}$ & $\begin{array}{l}-0.067 \\
(0.125)\end{array}$ & $\begin{array}{l}-0.375^{*} \\
(0.202)\end{array}$ \\
\hline GDP per capita & $\begin{array}{l}-0.031 \\
(0.072)\end{array}$ & $\begin{array}{l}-0.116 \\
(0.205)\end{array}$ & $\begin{array}{l}0.081 \\
(0.139)\end{array}$ & $\begin{array}{l}-0.037 \\
(0.162)\end{array}$ & $\begin{array}{l}-0.163 \\
(0.157)\end{array}$ & $\begin{array}{l}0.391^{* *} \\
(0.152)\end{array}$ & $\begin{array}{l}-0.271 \\
(0.204)\end{array}$ \\
\hline Population & $\begin{array}{c}-0.276^{*} \\
(0.140)\end{array}$ & $\begin{array}{l}0.707 \\
(0.467)\end{array}$ & $\begin{array}{l}-0.164 \\
(0.327)\end{array}$ & $\begin{array}{l}-0.211 \\
(0.300)\end{array}$ & $\begin{array}{l}-0.406 \\
(0.327)\end{array}$ & $\begin{array}{l}-0.561 \\
(0.342)\end{array}$ & $\begin{array}{l}-0.543 \\
(0.416)\end{array}$ \\
\hline Fraction 14- & $\begin{array}{l}0.279 \\
(0.204)\end{array}$ & $\begin{array}{l}-0.757 \\
(0.631)\end{array}$ & $\begin{array}{l}0.717 \\
(0.593)\end{array}$ & $\begin{array}{l}-0.181 \\
(0.433)\end{array}$ & $\begin{array}{l}-0.144 \\
(0.353)\end{array}$ & $\begin{array}{l}0.933^{* *} \\
(0.389)\end{array}$ & $\begin{array}{l}-0.473 \\
(0.508)\end{array}$ \\
\hline Fraction $65+$ & $\begin{array}{l}0.170 \\
(0.166)\end{array}$ & $\begin{array}{l}-0.740 * * \\
(0.373)\end{array}$ & $\begin{array}{l}0.023 \\
(0.229)\end{array}$ & $\begin{array}{l}0.781^{*} \\
(0.407)\end{array}$ & $\begin{array}{l}0.368 \\
(0.345)\end{array}$ & $\begin{array}{l}1.043^{* * *} \\
(0.369)\end{array}$ & $\begin{array}{l}-0.400 \\
(0.455)\end{array}$ \\
\hline Trade openness & $\begin{array}{l}0.117^{*} \\
(0.066)\end{array}$ & $\begin{array}{l}0.083 \\
(0.111)\end{array}$ & $\begin{array}{l}-0.131 \\
(0.079)\end{array}$ & $\begin{array}{l}-0.078 \\
(0.114)\end{array}$ & $\begin{array}{l}0.073 \\
(0.141)\end{array}$ & $\begin{array}{l}0.240^{*} \\
(0.134)\end{array}$ & $\begin{array}{l}0.456^{* * *} \\
(0.128)\end{array}$ \\
\hline Countries & 122 & 110 & 110 & 109 & 107 & 109 & 110 \\
\hline Observations & 2355 & 1890 & 1900 & 1824 & 1778 & 1834 & 1871 \\
\hline
\end{tabular}

Notes: All variables except democratization are in the natural logarithm. All estimations include a constant term, year dummies, and a dummy for the accrual basis of accounting, although we do not report the results here. ***, **, and $*$ indicate the $1 \%, 5 \%$, and $10 \%$ significance levels, respectively. The numbers in parentheses are robust standard errors clustered at the country level. 
Table 7: All types of transitions

\begin{tabular}{|c|c|c|c|c|c|c|c|}
\hline & $\begin{array}{l}\text { (1) } \\
\text { Total }\end{array}$ & $\begin{array}{l}(2) \\
\text { Health }\end{array}$ & $\begin{array}{l}\text { (3) } \\
\text { Education }\end{array}$ & $\begin{array}{l}(4) \\
\text { Social } \\
\text { protection }\end{array}$ & $\begin{array}{l}(5) \\
\text { Defense }\end{array}$ & $\begin{array}{l}(6) \\
\text { Economic } \\
\text { affairs }\end{array}$ & $\begin{array}{l}(7) \\
\text { General } \\
\text { public } \\
\text { services }\end{array}$ \\
\hline Full democratization & $\begin{array}{l}-0.022 \\
(0.050)\end{array}$ & $\begin{array}{l}0.377^{* * *} \\
(0.137)\end{array}$ & $\begin{array}{l}0.171 \\
(0.134)\end{array}$ & $\begin{array}{l}-0.030 \\
(0.082)\end{array}$ & $\begin{array}{l}-0.255^{* * *} \\
(0.069)\end{array}$ & $\begin{array}{l}-0.074 \\
(0.106)\end{array}$ & $\begin{array}{l}-0.201 \\
(0.139)\end{array}$ \\
\hline Partial democratization & $\begin{array}{l}0.081 \\
(0.125)\end{array}$ & $\begin{array}{l}-0.113 \\
(0.164)\end{array}$ & $\begin{array}{l}-0.043 \\
(0.167)\end{array}$ & $\begin{array}{l}0.086 \\
(0.175)\end{array}$ & $\begin{array}{l}0.026 \\
(0.145)\end{array}$ & $\begin{array}{l}-0.236 \\
(0.306)\end{array}$ & $\begin{array}{l}0.444^{* *} \\
(0.171)\end{array}$ \\
\hline Borderline democratization & $\begin{array}{l}0.103 \\
(0.135)\end{array}$ & $\begin{array}{l}-0.353^{* *} \\
(0.154)\end{array}$ & $\begin{array}{l}-0.469^{* * *} \\
(0.132)\end{array}$ & $\begin{array}{l}0.479^{* * *} \\
(0.130)\end{array}$ & $\begin{array}{l}0.067 \\
(0.149)\end{array}$ & $\begin{array}{l}0.307^{* *} \\
(0.142)\end{array}$ & $\begin{array}{l}-0.647^{* * *} \\
(0.150)\end{array}$ \\
\hline Reversals & $\begin{array}{l}0.087^{* *} \\
(0.033)\end{array}$ & $\begin{array}{l}-0.038 \\
(0.090)\end{array}$ & $\begin{array}{l}0.065 \\
(0.072)\end{array}$ & $\begin{array}{l}0.247^{* *} \\
(0.114)\end{array}$ & $\begin{array}{l}-0.131 \\
(0.096)\end{array}$ & $\begin{array}{l}-0.055 \\
(0.087)\end{array}$ & $\begin{array}{l}0.121 \\
(0.114)\end{array}$ \\
\hline GDP per capita & $\begin{array}{l}-0.040 \\
(0.073)\end{array}$ & $\begin{array}{l}-0.216 \\
(0.219)\end{array}$ & $\begin{array}{l}0.036 \\
(0.142)\end{array}$ & $\begin{array}{l}0.021 \\
(0.161)\end{array}$ & $\begin{array}{l}-0.144 \\
(0.174)\end{array}$ & $\begin{array}{l}0.375^{* *} \\
(0.164)\end{array}$ & $\begin{array}{c}-0.334^{*} \\
(0.185)\end{array}$ \\
\hline Population & $\begin{array}{l}-0.345^{* *} \\
(0.137)\end{array}$ & $\begin{array}{l}0.662 \\
(0.491)\end{array}$ & $\begin{array}{l}-0.099 \\
(0.327)\end{array}$ & $\begin{array}{l}-0.295 \\
(0.297)\end{array}$ & $\begin{array}{l}-0.385 \\
(0.357)\end{array}$ & $\begin{array}{c}-0.582^{*} \\
(0.349)\end{array}$ & $\begin{array}{l}-0.640 \\
(0.418)\end{array}$ \\
\hline Fraction 14- & $\begin{array}{l}0.278 \\
(0.204)\end{array}$ & $\begin{array}{l}-1.005 \\
(0.707)\end{array}$ & $\begin{array}{l}0.598 \\
(0.606)\end{array}$ & $\begin{array}{l}-0.021 \\
(0.423)\end{array}$ & $\begin{array}{l}-0.108 \\
(0.365)\end{array}$ & $\begin{array}{l}0.975^{* *} \\
(0.410)\end{array}$ & $\begin{array}{l}-0.555 \\
(0.558)\end{array}$ \\
\hline Fraction $65+$ & $\begin{array}{l}0.213 \\
(0.159)\end{array}$ & $\begin{array}{c}-0.622 * \\
(0.371)\end{array}$ & $\begin{array}{l}0.028 \\
(0.232)\end{array}$ & $\begin{array}{l}0.770^{*} \\
(0.409)\end{array}$ & $\begin{array}{l}0.341 \\
(0.358)\end{array}$ & $\begin{array}{l}1.028^{* * *} \\
(0.379)\end{array}$ & $\begin{array}{l}-0.298 \\
(0.448)\end{array}$ \\
\hline Trade openness & $\begin{array}{l}0.112^{*} \\
(0.059)\end{array}$ & $\begin{array}{l}0.103 \\
(0.118)\end{array}$ & $\begin{array}{c}-0.136^{*} \\
(0.081)\end{array}$ & $\begin{array}{l}-0.097 \\
(0.114)\end{array}$ & $\begin{array}{l}0.075 \\
(0.139)\end{array}$ & $\begin{array}{l}0.277^{* *} \\
(0.113)\end{array}$ & $\begin{array}{l}0.369^{* * *} \\
(0.106)\end{array}$ \\
\hline Countries & 122 & 110 & 110 & 109 & 107 & 109 & 110 \\
\hline Observations & 2355 & 1890 & 1900 & 1824 & 1778 & 1834 & 1871 \\
\hline
\end{tabular}

Notes: All variables except democratization are in the natural logarithm. All estimations include a constant term, year dummies, and a dummy for the accrual basis of accounting, although we do not report the results here. ***, **, and $*$ indicate the $1 \%, 5 \%$, and $10 \%$ significance levels, respectively. The numbers in parentheses are robust standard errors clustered at the country level. 
Table A1: List of countries

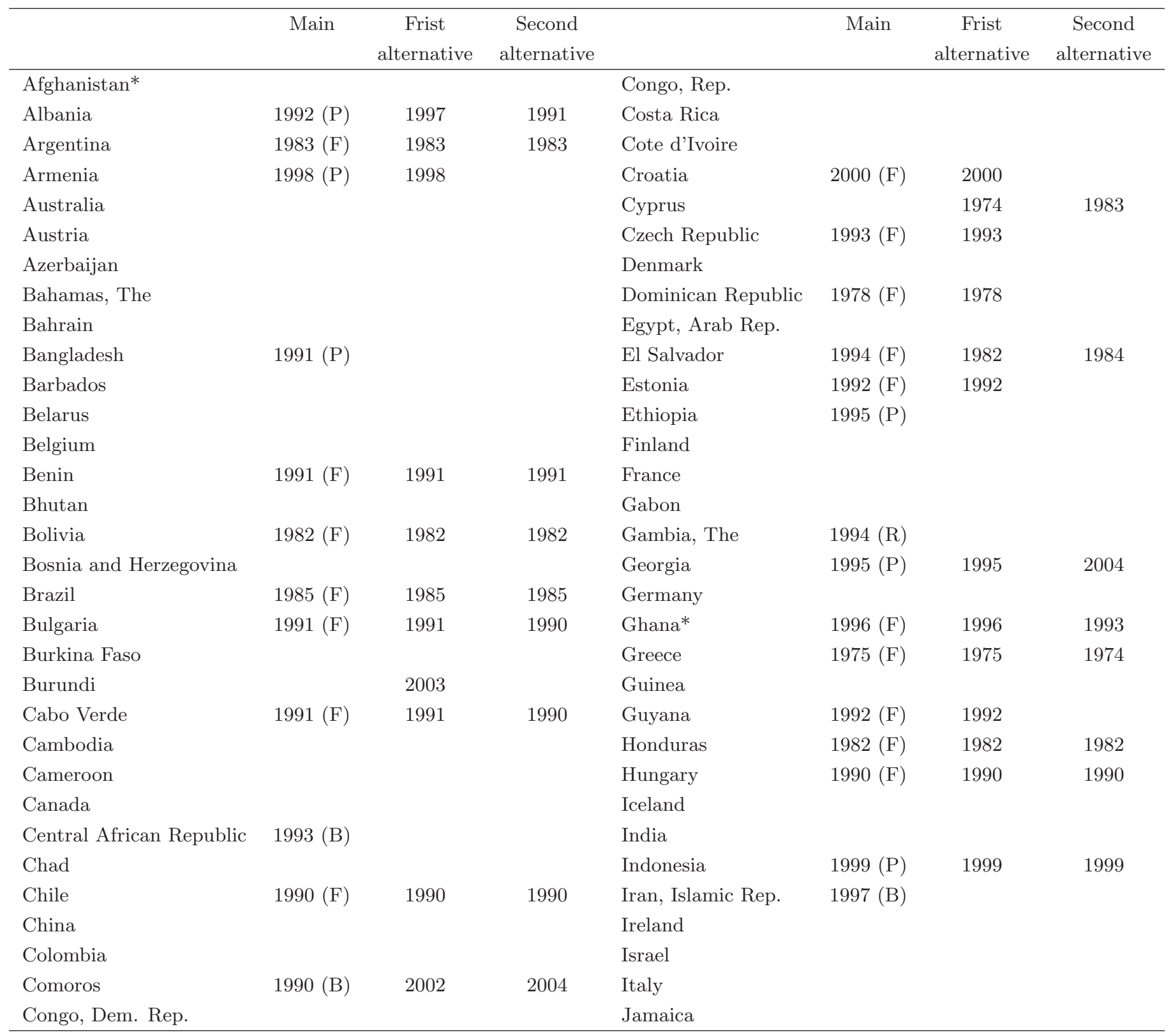


Table A1 (Continued)

\begin{tabular}{|c|c|c|c|c|c|c|c|}
\hline & Main & $\begin{array}{c}\text { Frist } \\
\text { alternative }\end{array}$ & $\begin{array}{c}\text { Second } \\
\text { alternative }\end{array}$ & & Main & $\begin{array}{c}\text { Frist } \\
\text { alternative }\end{array}$ & $\begin{array}{c}\text { Second } \\
\text { alternative }\end{array}$ \\
\hline Japan & & & & Romania & $1990(\mathrm{~F})$ & 1990 & 1990 \\
\hline Jordan* & & & & Russian Federation & $1993(\mathrm{P})$ & & \\
\hline Kazakhstan & & & & Rwanda & & & \\
\hline Korea, Rep. & $1988(\mathrm{~F})$ & 1988 & 1988 & Senegal & $2000(\mathrm{~F})$ & 2000 & 2000 \\
\hline Kuwait & & & & Seychelles & & & \\
\hline Latvia & $1993(\mathrm{~F})$ & 1993 & & Singapore & & & \\
\hline Lesotho & $1993(\mathrm{P})$ & 1999 & & Slovak Republic & $1993(\mathrm{~F})$ & 1993 & \\
\hline Liberia & & 2004 & & Slovenia & $1992(\mathrm{~F})$ & 1992 & \\
\hline Lithuania & $1993(\mathrm{~F})$ & 1993 & & South Africa & $1994(\mathrm{~F})$ & 1994 & \\
\hline Luxembourg & & & & Spain & $1978(\mathrm{~F})$ & 1978 & 1977 \\
\hline Macedonia, FYR & $1991(\mathrm{P})$ & 1991 & & Sri Lanka & & & 1989 \\
\hline Madagascar & $1993(\mathrm{P})$ & & 1993 & Suriname & $1991(\mathrm{P})$ & 1991 & 1991 \\
\hline Malaysia & & & & Sweden & & & \\
\hline Mali & $1992(\mathrm{~F})$ & 1992 & 1992 & Switzerland & & & \\
\hline Malta & & & & Syrian Arab Republic & & & \\
\hline Mauritius & & & & Tajikistan & & & \\
\hline Mexico & $1997(\mathrm{~F})$ & 1997 & 2000 & Thailand & $1992(\mathrm{~F})$ & & \\
\hline Moldova & $1994(\mathrm{P})$ & 1994 & & Togo & & & \\
\hline Mongolia & $1993(\mathrm{~F})$ & 1993 & 1990 & Tonga & & & \\
\hline Morocco & & & & Trinidad and Tobago & & & \\
\hline Nepal & $1991(\mathrm{~B})$ & 2006 & & Tunisia & & & \\
\hline Netherlands & & & & Turkey & $1983(\mathrm{P})$ & 1983 & 1983 \\
\hline New Zealand & & & & Ukraine & $1994(\mathrm{P})$ & 1994 & \\
\hline Nicaragua & $1990(\mathrm{P})$ & 1990 & 1984 & United Kingdom & & & \\
\hline Niger & $1999(\mathrm{~B})$ & & 2000 & United States & & & \\
\hline Norway & & & & Uruguay & $1985(\mathrm{~F})$ & 1985 & 1985 \\
\hline Pakistan & $1988(\mathrm{~B})$ & & & Venezuela, RB & & & \\
\hline Panama & $1994(\mathrm{~F})$ & 1994 & 1989 & Zambia & $1991(\mathrm{P})$ & 1991 & \\
\hline Paraguay & $1993(\mathrm{P})$ & 1993 & 1989 & Zimbabwe & $1987(\mathrm{R})$ & & \\
\hline Peru & $1980(\mathrm{~F})$ & 1993 & 2001 & & & & \\
\hline Poland & $1990(\mathrm{~F})$ & 1990 & 1989 & & & & \\
\hline Portugal & $1976(\mathrm{~F})$ & 1976 & 1976 & & & & \\
\hline
\end{tabular}

Notes: The numbers refer to the year of democratization. "Main" is based on Papaioannou and Siourounis (2008a) and $(\mathrm{F}),(\mathrm{P}),(\mathrm{B})$, and $(\mathrm{R})$ mean full, partial, and borderline democratization, and reversals, respectively. Note that the three countries (marked with ${ }^{*}$ ) are not included among the 122 countries in the main sample. We define successful democratization using the data of Cheibub et al. (2010) and Acemoglu et al. (2014). "First and second alternatives" are based on Acemoglu et al. (2014) and Cheibub et al. (2010), respectively, and are defined as democratization satisfying the following conditions: (1) the country's democratization is the most recent in the sample period, and (2) its final democratic regime had persisted at least for five years until the end of the sample period. 
Table A2: Data definitions and sources

\begin{tabular}{|c|c|c|}
\hline Variable & Description & Source \\
\hline Total & Total government expenditure as a share of GDP & IMF $(1999,2005,2013)$ \\
\hline Health & $\begin{array}{l}\text { Expenditure on health as a share of GDP. Health includes medical } \\
\text { products, appliances and equipment, outpatient services, hospital ser- } \\
\text { vices, public health services, and so on. See GFSM } 2001 \text { for a detailed } \\
\text { definition }\end{array}$ & IMF $(1999,2005,2013)$ \\
\hline Education & $\begin{array}{l}\text { Expenditure on education as a share of GDP. Education includes pre- } \\
\text { primary, primary, secondary, postsecondary, nontertiary, and tertiary } \\
\text { education, and so on. See GFSM } 2001 \text { for a detailed definition }\end{array}$ & $\operatorname{IMF}(1999,2005,2013)$ \\
\hline Social protection & $\begin{array}{l}\text { Expenditure on social protection as a share of GDP. Social protection } \\
\text { includes protection against sickness and disability, old age, unemploy- } \\
\text { ment, and protection for survivors, family and children, housing, and } \\
\text { so on. See GFSM } 2001 \text { for a detailed definition }\end{array}$ & $\operatorname{IMF}(1999,2005,2013)$ \\
\hline Defense & $\begin{array}{l}\text { Expenditure on defense as a share of GDP. Defense includes military } \\
\text { defense, civil defense, and so on. See GFSM } 2001 \text { for a detailed defini- } \\
\text { tion }\end{array}$ & $\operatorname{IMF}(1999,2005,2013)$ \\
\hline Economic affairs & $\begin{array}{l}\text { Expenditure on economic affairs as a share of GDP. Economic affairs } \\
\text { include general economic, commercial, and labor affairs; affairs pertain- } \\
\text { ing to agriculture, forestry, fishing, hunting, fuel and energy, mining, } \\
\text { manufacturing, construction, transport, and communication, and so on. } \\
\text { See GFSM } 2001 \text { for a detailed definition }\end{array}$ & $\operatorname{IMF}(1999,2005,2013)$ \\
\hline General public services & $\begin{array}{l}\text { Expenditure on general public services as a share of GDP. General } \\
\text { public services include executive and legislative organs, financial and } \\
\text { fiscal affairs, external affairs, foreign economic aid, and so on. See } \\
\text { GFSM } 2001 \text { for a detailed definition }\end{array}$ & $\operatorname{IMF}(1999,2005,2013)$ \\
\hline GDP per capita & Real GDP per capita in constant 2005 U.S. dollars & World Bank (2014) \\
\hline Population & Total population & World Bank (2014) \\
\hline Fraction 14- & $\begin{array}{l}\text { Fraction of population between the ages } 0 \text { and } 14 \text { as a share of the total } \\
\text { population }\end{array}$ & World Bank (2014) \\
\hline Fraction $65+$ & $\begin{array}{l}\text { Fraction of population aged } 65 \text { and above as a share of the total pop- } \\
\text { ulation }\end{array}$ & World Bank (2014) \\
\hline Trade openness & The sum of exports and imports divided by GDP & World Bank (2014) \\
\hline Inequality & $\begin{array}{l}\text { Estimate of the Gini index of inequality in equivalized (square root } \\
\text { scale) household disposable (post-tax, post-transfer) income }\end{array}$ & Solt $(2009)$ \\
\hline Inflation & Inflation based on the GDP deflator. & World Bank (2014) \\
\hline
\end{tabular}


Table A3: Descriptive statistics

\begin{tabular}{lrrrrr}
\hline Variables & Observations & \multicolumn{1}{c}{ Mean } & Standard deviation & Minimum & Maximum \\
\hline Total & 2881 & 29.667 & 11.767 & 3.450 & 156.950 \\
Health & 2269 & 2.500 & 1.987 & 0.015 & 9.910 \\
Education & 2278 & 3.262 & 1.787 & 0.150 & 12.530 \\
Social protection & 2192 & 7.592 & 6.028 & 0.011 & 25.980 \\
Defense & 2137 & 2.632 & 4.026 & 0.026 & 107.040 \\
Economic affairs & 2201 & 4.959 & 3.779 & 0.470 & 29.588 \\
General public services & 2252 & 7.269 & 4.334 & 0.390 & 62.640 \\
GDP per capita & 4353 & 9183.209 & 12908.960 & 50.042 & 87716.730 \\
Population & 4872 & 37600000 & 133000000 & 56068 & 1340000000 \\
Fraction 14- & 4875 & 32.498 & 10.588 & 13.269 & 50.330 \\
Fraction 65+ & 4875 & 7.311 & 4.577 & 1.349 & 22.962 \\
Trade openness & 4296 & 76.617 & 48.046 & 6.320 & 439.657 \\
Inequality & 3281 & 37.060 & 10.676 & 15.370 & 75.256 \\
Inflation & 4366 & 53.026 & 600.947 & -29.173 & 26762.020 \\
\hline
\end{tabular}

Notes: These statistics are calculated based on 125 countries over the period 1972-2010. 